\title{
Cellular Blue Nevus
}

National Cancer Institute

\section{Source}

National Cancer Institute. Cellular Blue Nevus. NCI Thesaurus. Code C4241.

A blue nevus characterized by a multinodular cellular infiltrate with a dumb-bell architecture occupying the reticular dermis. The cellular infiltrate often extends into the subcutaneous tissue. The cellular infiltrate is composed of spindle-shaped melanocytes with pale cytoplasm alternating with bundles of pig mented spindle-shaped melanocytes. In occasional cases an increased mitotic activity, focal necrosis, and nuclear pleomorphism may be seen. Such cases with atypical features may have an uncertain malignant potential. 